\title{
PENINGKATAN HASIL BELAJAR SISWA MELALUI MODEL PEMBELAJARAN KOOPERATIF TIPE THINK PAIR SHARE (TPS) DI SMK NEGERI 1 MAGELANG
}

\author{
Carolus Ryan Putra Praditya* \& Kir Haryana \\ Pendidikan Teknik Otomotif, Fakultas Teknik, Universitas Negeri Yogyakarta \\ Email: putrapraditya29@gmail.com
}

\begin{abstract}
This research aims to determine the increase in learning outcomes in the subject of Automotive Basic Technology class X Department of Automotive Engineering SMK Negeri 1 Magelang 2018/2019 Academic Year using the application of cooperative learning models Think Pair Share (TPS) type. This research is a class action research. Data collection techniques used in this study used observation and tests. The steps undertaken in this study were begun with observations to find out the students' initial abilities in the material used, then implemented a Think Pair Share (TPS) type of cooperative learning model with a continuous learning cycle, and ended with a posttest at each end of learning. The results showed that the application of learning using the Cooperative learning model Think Pair Share (TPS) type can improve student learning outcomes in automotive basic technology subjects in class X OC SMK Negeri 1 Magelang. On observation, the average value of 55, in the first cycle the average student learning outcomes of 83, then in the second cycle the average student learning outcomes of 90 , thus the average test in the first cycle increased by 28 points or by $56,6 \%$ compared to observations, the average test in cycle II increased by 7 points or $8.4 \%$ compared to the test in cycle I.
\end{abstract}

Key Words: cooperative learning, Think Pair Share (TPS), and learning outcomes

\begin{abstract}
Abstrak
Penelitian ini bertujuan untuk mengetahui peningkatan hasil belajar pada mata pelajaran Teknologi Dasar Otomotif kelas X Jurusan Teknik Otomotif SMK Negeri 1 Magelang Tahun Ajaran 2018/2019 menggunakan penerapan model pembelajaran kooperatif tipe Think Pair Share (TPS). Penelitian ini merupakan penelitian tindakan kelas. Teknik pengumpulan data yang digunakan dalam penelitian ini menggunakan observasi dan tes. Langkah-langkah yang dilakukan dalam penelitian ini yaitu diawali dengan observasi untuk mengetahui kemampuan awal siswa pada materi yang digunakan, kemudian mengimplementasikan model pembelajaran kooperatif tipe Think Pair Share (TPS) dengan siklus pembelajaran berkelanjutan, dan diakhiri dengan posttest di setiap akhir pembelajaran. Hasil penelitian menunjukkan bahwa penerapan pembelajaran dengan menggunakan model pembelajaran kooperatif tipe Think Pair Share (TPS) dapat meningkatkan hasil belajar siswa pada mata pelajaran teknologi dasar otomotif pada kelas X OC SMK Negeri 1 Magelang. Pada observasi, nilai rata-rata sebesar 55, pada siklus I rata-rata hasil belajar siswa sebesar 83 , kemudian pada siklus II rata-rata hasil belajar siswa sebesar 90, dengan demikian rata-rata tes pada siklus I meningkat 28 poin atau sebesar 56,6\% dibandingkan dengan observasi, rata-rata tes pada siklus II meningkat 7 poin atau sebesar $8,4 \%$ dibandingkan tes pada siklus I.
\end{abstract}

Kata Kunci: pembelajaran kooperatif, Think Pair Share (TPS), dan hasil belajar

\section{PENDAHULUAN}

SMK memiliki tujuan umum dan tujuan khusus. Garis besar dari tujuan umum SMK adalah untuk mengembangkan potensi peserta didik baik dalam hal menjadi warga negara yang baik, 


\section{Carolus Ryan Putra Praditya, Kir Haryana}

memiliki wawasan kebangsaan maupun memiliki kepedulian terhadap lingkungan hidup. Selain itu dalam tujuan khusus juga terdapat tujuan bahwa peserta didik harus mengembangkan sikap profesional dalam bidang keahlian yang diminatinya dan mampu mengembangkan diri di kemudian hari baik secara mandiri maupun melalui jenjang pendidikan yang lebih tinggi. Salah satu cara mengukur perkembangan kognitif peserta didik adalah dengan diadakannya Ulangan Harian (UH). Terdapat standar yang digunakan untuk mengukur pencapaian hasil kompetensi belajar siswa. Standar tersebut adalah Kriteria Ketuntasan Minimal (KKM). Dalam praktiknya, masih terjadi permasalahan terkait UH yang dilaksanakan oleh sekolah. Permasalahan tersebut adalah masih banyak siswa yang memiliki nilai di bawah KKM. Berdasarkan observasi yang dilakukan di SMK Negeri 1 Magelang, peneliti mendapatkan hasil bahwa masih banyak siswa yang memiliki nilai UH dibawah KKM. Peneliti melakukan observasi di kelas X OC yang berjumlah 32 siswa. Observasi dilakukan pada mata pelajaran Teknologi Dasar Otomotif. Dari hasil observasi yang telah dilakukan, terdapat 29 siswa dari 32 siswa atau sebesar $60 \%$ dari seluruh siswa yang belum memenuhi KKM pada mata pelajaran Teknologi Dasar Otomotif. KKM pada mata pelajaran Teknologi Dasar Otomotif adalah 75. Hal ini menunjukkan bahwa masih ada permasalahan dalam proses pembelajaran mata pelajaran Teknologi Dasar Otomotif di kelas X OC. Sebagian besar siswa atau sekitar 90,6\% siswa masih memiliki nilai UH yang kurang dari KKM.

Pada hasil observasi didapatkan hasil bahwa siswa kurang dilibatkan secara aktif dalam pembelajaran sehingga siswa tidak dapat mengembangkan kemampuan berpikir kritis dan mengemukakan pendapat yang dimilikinya. Oleh karena itu dibutuhkan model pembelajaran yang dapat meningkatkan keaktifan siswa agar hasil belajar siswa dapat meningkat, misalkan saja Problem based learning (Nurtanto \& Sofyan, 2015; Tafakur \& Suyanto, 2015). Peneliti memilih model pembelajaran kooperatif tipe Think Pair Share (TPS) dalam penelitian ini. Model pembelajaran ini dipilih karena pada model ini materi akan dipelajari atau diulang sebanyak 4 kali sesuai dengan tahapan pada model ini. Jika dalam model pembelajaran lain siswa akan memulai pembelajaran sudah dalam kelompok sehingga terdapat kecenderungan ada siswa yang tidak terlibat aktif dalam pembelajaran atau hanya bergantung pada teman di kelompoknya. Namun dalam model pembelajaran ini siswa diberikan kesempatan untuk berpikir secara mandiri terlebih dahulu sehingga masing-masing siswa terlibat secara aktif dalam pembelajaran.

Berbagai penelitian menunjukkan bahwa pembelajaran dengan model pembelajaran kooperatif tipe TPS efektif digunakan untuk meningkatkan hasil belajar siswa. L. Surayya, I W. Subagia dan I N. Tika (2014) menunjukkan bahwa (1) terdapat perbedaan hasil belajar antara siswa yang mengikuti model pembelajaran TPS dengan siswa yang mengikuti model 
pembelajaran konvensional (MPK). Fani Nurlaila dan I.G.P Asto Buditjahjanto (2013) menunjukkan bahwa hasil belajar siswa yang menggunakan tipe pembelajaran Think Pair Share lebih tinggi atau berbeda secara signifikan dibandingkan dengan hasil belajar siswa yang menggunakan tipe pembelajaran Jigsaw. Berdasarkan dari uraian dan penjelasan diatas, maka peneliti ingin melakukan penelitian untuk mengetahui peningkatan hasil belajar siswa kelas $\mathrm{X}$ OC SMK N 1 Magelang mata pelajaran Teknologi Dasar Otomotif dengan menggunakan model pembelajaran kooperatif tipe Think Pair Share (TPS).

Think Pair Share (TPS) adalah suatu model pembelajaran kooperatif yang memberi siswa waktu untuk berpikir dan merespons serta saling membantu satu sama lain (Shoimin, 2014: 208). Manfaat pembelajaran kooperatif tipe Think Pair Share antara lain 1) siswa akan terlatih menerapkan konsep karena bertukar pendapat dan pemikiran dengan temannya untuk mendapatkan kesepakatan dalam memecahkan masalah, 2) siswa dapat meningkatkan keberaniannya untuk berpendapat karena siswa diberi kesempatan untuk mencari pendapatnya sendiri sebelum mendiskusikannya dengan teman, 3) siswa lebih aktif dalam pembelajaran karena menyelesaikan tugasnya dalam kelompok, sehingga pembelajaran tidak hanya berpusat pada guru, dan 4) siswa mendapatkan kesempatan untuk mempresentasikan hasil diskusinya dengan seluruh kelas sehingga seluruh kelas mendapatkan informasi yang beragam dari kegiatan yang telah dilakukan (Hartina, 2008: 12).

Berdasarkan pemaparan dalam latar belakang masalah diatas, maka permasalahan yang muncul diidentifikasi diantaranya adalah sebanyak 29 dari 32 siswa atau 90,6\% siswa kelas X OC SMK N 1 Magelang memiliki nilai UH yang masih dibawah KKM dengan rata-rata nilai sebesar 64 pada mata pelajaran Teknologi Dasar Otomotif, Sebagian besar siswa kurang memahami materi yang telah dijelaskan oleh guru, hal ini dapat ditunjukkan dengan 90,6\% siswa kelas X OC SMK N 1 Magelang memiliki nilai UH dibawah KKM dan Metode ceramah yang diterapkan guru kurang membuat siswa mengerti materi yang sedang dipelajari sehingga diperlukan model pembelajaran yang lebih membuat siswa aktif dan paham terhadap materi yang dipelajari. Hal ini berdasarkan data pada hasil nilai Ulangan Harian siswa yang sebagian besar masih kurang dari KKM. Sesuai dengan masalah tersebut, tujuan dalam penelitian ini adalah mengetahui peningkatan hasil belajar siswa kelas X OC SMK N 1 Magelang dalam mata pelajaran Teknologi Dasar Otomotif menggunakan model pembelajaran Kooperatif tipe Think Pair Share (TPS). Sedangkan manfaat dari penelitian yang dilakukan ini antara lain adalah siswa akan mendapat pengalaman baru dalam belajar dengan menggunakan model pembelajaran kooperatif tipe Think Pair Share pada mata pelajaran Teknologi Dasar Otomotif, guru mendapatkan pengalaman tentang model pembelajaran kooperatif tipe Think Pair Share pada mata pelajaran Teknologi Dasar Otomotif, sehingga model tersebut dapat menjadi 


\section{Carolus Ryan Putra Praditya, Kir Haryana}

referensi bagi guru dalam mengajar, sekolah akan menambah pengetahuan dan wawasan tentang penerapan model pembelajaran kooperatif tipe Think Pair Share yang digunakan dalam mata pelajaran Teknologi Dasar Otomotif dan penelitian ini memberikan pengetahuan baru serta masukan untuk mengetahui upaya peningkatan hasil belajar siswa dengan menggunakan model pembelajaran kooperatif tipe Think Pair Share pada mata pelajaran Teknologi Dasar Otomotif.

\section{METODE}

Penelitian ini menggunakan jenis penelitian tindakan kelas (PTK) dengan desain penelitian menurut Kemmis \& McTaggart. PTK adalah penelitian tindakan (action research) yang dilakukan dengan tujuan memperbaiki mutu praktik pembelajaran di kelasnya. Menurut Arikunto, dkk (2007: 58), PTK adalah penelitian tindakan (action research) yang dilakukan dengan tujuan memperbaiki mutu praktik pembelajaran di kelasnya. Penelitian ini dilaksanakan di SMK Negeri 1 Magelang, berlokasi di Jalan Cawang No. 02, Jurang Ombo, Magelang Selatan, Magelang 56123. Penelitian ini dilaksanakan kurang lebih selama satu bulan (mulai dari kegiatan persiapan hingga pelaksanaan tindakan) yang mulai dilaksanakan pada bulan April 2019 - Mei 2019.

Subyek penelitian dalam penelitian ini adalah siswa kelas X OC di SMK Negeri 1 Magelang yang mengikuti Mata Pelajaran Teknologi Dasar Otomotif. Pemilihan subyek penelitian berdasarkan permasalahan hasil observasi awal yang telah dilakukan oleh peneliti dan rekomendasi guru pengampu mata pelajaran. Pada penelitian ini dilakukan 2 siklus penelitian. Pada setiap siklus penelitian terdapat 4 tahapan penelitian. Tahapan tersebut adalah perencanaan, pelaksanaan, pengamatan/observasi, dan refleksi. Pada tiap siklus penelitian dilakukan sebanyak 2 kali pertemuan. Tiap pertemuan dilakukan dengan waktu 2 x 45 menit.

Dalam penelitian ini menggunakan dua jenis instrumen penelitian, yaitu tes untuk mengukur hasil belajar siswa dan non tes untuk mengukur proses pembelajaran yang berlangsung dengan menggunakan model pembelajaran kooperatif tipe Think Pair Share oleh guru dan untuk mengamati kebutuhan siswa saat pembelajaran berlangsung. Dalam penelitian ini menggunakan dua teknik analisis data, yaitu nilai rata-rata kelas dan presentase jumlah siswa yang tuntas belajar. 


\section{HASIL DAN PEMBAHASAN}

\section{Rata-rata Nilai Kelas}

Berdasarkan hasil penilaian tes dari setiap siklus meliputi hasil observasi, post test siklus I, post test siklus II yang sudah dilakukan diperoleh hasil seperti pada gambar berikut ini.

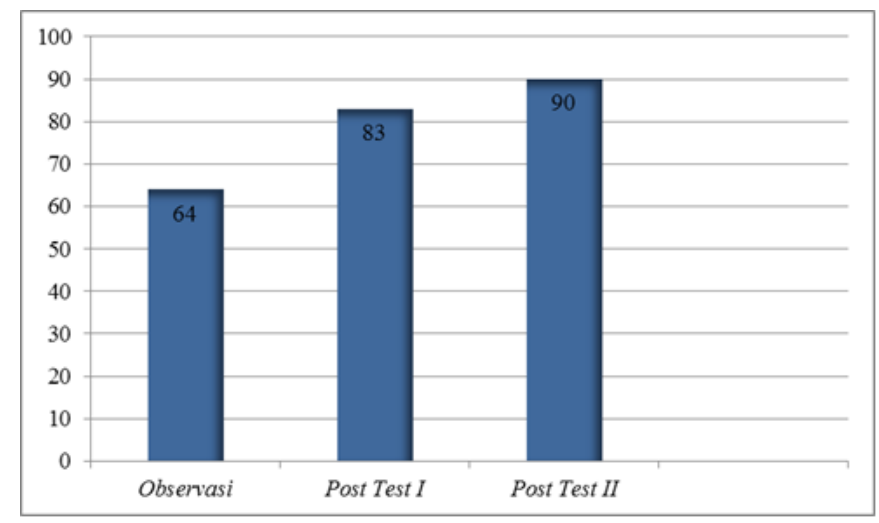

Gambar 1. Grafik Nilai Rata-rata Hasil Tes

Berdasarkan data pada grafik diatas, didapatkan data rata-rata hasil belajar siswa pada saat Observasi sebesar 64 dan rata-rata hasil belajar siswa pada saat siklus I sebesar 83. Peningkatan hasil belajar dari observasi ke siklus I sebesar 19 poin atau meningkat sebesar 29,6\%. Sedangkan rata-rata hasil belajar siklus II siswa sebesar 90. Sehingga peningkatan hasil belajar siswa dari siklus I ke siklus II sebesar 7 poin atau sebesar $8,4 \%$. Hal ini dapat menjadi indikator keberhasilan proses pembelajaran yang menerapkan model pembelajaran kooperatif tipe Think Pair Share . Dari data tersebut dapat dilihat bahwa hasil belajar siswa dengan menggunakan model pembelajaran kooperatif tipe Think Pair Share sudah mengalami peningkatan di setiap siklusnya. Hal ini dapat ditunjukkan dengan meningkatnya rata-rata hasil belajar siswa pada setiap siklusnya. Namun masih terdapat beberapa siswa yang belum mampu meningkatkan hasil belajarnya sehingga belum mampu mencapai KKM. Hal tersebut perlu dicari penyebab dan solusinya yang tepat agar semua siswa tidak hanya memiliki peningkatan hasil belajar namun juga dapat memenuhi KKM yang telah ditentukan.

Dari hasil penelitian yang telah dilakukan, dapat disimpulkan bahwa model pembelajaran kooperatif tipe Think Pair Share dapat meningkatkan hasil belajar siswa. Hal ini ditandai dengan meningkatnya nilai rata-rata hasil belajar siswa dari siklus I ke siklus II. Langkahlangkah dalam pelaksanaan pembelajaran menggunakan model pembelajaran kooperatif tipe Think Pair Share membuat siswa lebih tertata dalam proses pembelajaran yang dilakukan. Selain itu, setiap siswa dituntut aktif selama proses pembelajaran berlangsung mulai dari pendahuluan sampai evaluasi. Pada model pembelajaran yang digunakan menekankan 


\section{Carolus Ryan Putra Praditya, Kir Haryana}

kerjasama antar setiap siswa baik dengan teman sebangku maupun kelompok kecil, siswa dituntut untuk saling berbagi informasi atau pengetahuan mengenai materi pembelajaran antara satu siswa dengan siswa lain. Siswa yang telah memahami materi pembelajaran dapat mengembangkan kemampuannya dengan membantu siswa lain dalam memahami materi pembelajaran tersebut sehingga siswa akan lebih memahami materi pembelajaran secara mendalam.

\section{Ketuntasan Siswa}

Berdasarkan pada hasil observasi sebagian besar siswa belum mampu mencapai KKM yang telah ditentukan oleh sekolah. Sebanyak 29 siswa belum mampu mencapai KKM. Sedangkan pada saat pelaksanaan siklus I terdapat 5 siswa yang belum mencapai KKM. Pada pelaksanaan siklus II terdapat 1 siswa yang belum mencapai KKM. Dari data tersebut dapat dilihat terdapat peningkatan siswa yang mencapai KKM pada setiap siklus. Dari observasi ke siklus I peningkatan jumlah siswa yang mencapai KKM sebanyak 24 siswa. Sedangkan peningkatan jumlah siswa yang mencapai KKM pada siklus I ke siklus II sebanyak 4 siswa. Dari data diatas dapat disimpulkan bahwa penerapan model pembelajaran kooperatif tipe Think Pair Share pada proses pembelajaran dapat meningkatkan hasil belajar yang dapat dilihat dari peningkatan jumlah siswa yang mencapai KKM pada tiap siklus.

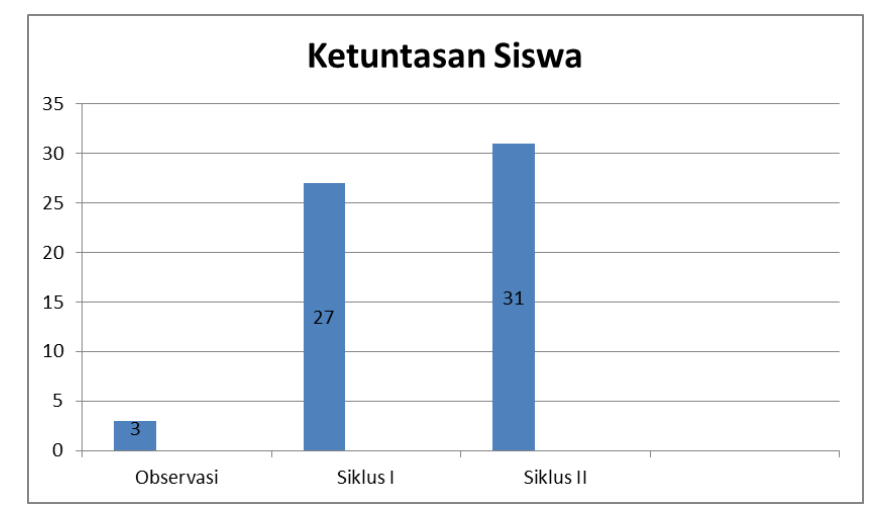

Gambar 14. Grafik Ketuntasan Siswa

Dari hasil penelitian yang dilakukan dapat dilihat bahwa peningkatan jumlah siswa yang mencapai KKM maupun rata-rata nilai hasil belajar siswa pada setiap siklus disebabkan oleh keaktifan siswa selama proses pembelajaran menggunakan model pembelajaran kooperatif tipe Think Pair Share berlangsung. Melalui model pembelajaran kooperatif tipe Think Pair Share siswa dituntut untuk aktif dalam membangun pengetahuannya sendiri kemudian mengembangkan pengetahuan yang didapatkan dengan memperoleh informasi dari teman sebaya baik secara pair maupun share. Siswa yang telah memahami pembelajaran secara lebih mendalam dapat membantu siswa lain dalam mengembangkan kemampuannya dengan 
membantu siswa yang kurang memahami materi pembelajaran tersebut, sehingga siswa yang sudah paham akan lebih paham lagi dan siswa yang kurang paham menjadi paham dengan bantuan dari temannya. Penerapan model pembelajaran kooperatif tipe Think Pair Share ini membuat siswa tidak hanya sekedar menghafal namun memahami pembelajaran yang sedang dipelajari.

Pada siklus II masih terdapat siswa yang belum mencapai KKM dengan nilai sebesar 65 . Terdapat beberapa faktor yang dapat mempengaruhi siswa belum dapat mencapai KKM. Faktor tersebut antara lain adalah kemampuan siswa masih kurang dalan memahami materi pembelajaran yang sedang dipelajari. Faktor lain yaitu siswa yang kurang mampu bekerja sama di dalam sebuah kelompok sehingga tidak dapat bertukar pikiran tentang yang diketahui dengan teman lain. Hal ini dapat membuat siswa tidak mendapat pengetahuan lebih dari temannya sehingga siswa kurang mampu memahami materi yang sedang dipelajari. Untuk mengatasi masalah tersebut, guru memberikan penugasan kepada siswa yang belum mencapai KKM dengan materi yang telah dipelajari. Dengan adanya penugasan tersebut diharapkan siswa dapat lebih memahami materi yang sudah dipelajari.

\section{SIMPULAN}

Berdasarkan hasil penelitian yang telah dilaksanakan dalam dua siklus maka dapat disimpulkan bahwa penerapan pembelajaran dengan menggunakan model pembelajaran kooperatif tipe Think Pair Share (TPS) dapat meningkatkan hasil belajar siswa pada mata pelajaran teknologi dasar otomotif dengan materi kelistrikan dasar kendaraan ringan kelas $\mathrm{X}$ OC SMK Negeri 1 Magelang. Peningkatan hasil belajar tersebut dapat dilihat dari hasil belajar disetiap siklus yang dilakukan. Pada pra siklus, nilai rata-rata sebesar 55, pada siklus I rata-rata hasil belajar siswa sebesar 83, kemudian pada siklus II rata-rata hasil belajar siswa sebesar 90, dengan demikian rata-rata tes pada siklus I meningkat 28 poin atau sebesar $56,6 \%$ dibandingkan dengan pra siklus, rata-rata tes pada siklus II meningkat 7 poin atau sebesar $8,4 \%$ dibandingkan tes pada siklus I.

Berdasarkan hasil penelitian dan kesimpulan di atas, maka peneliti menyarankan beberapa hal sebagai berikut bagi peneliti khususnya yang akan melakukan penelitan tindakan kelas menggunakan model pembelajaran kooperatif tipe Think Pair Share (TPS) sebaiknya menyiapkan segala sesuatu dengan matang, terutama komunikasi dengan guru pengampu mata pelajaran yang bersangkutan untuk membantu proses penelitian, siswa diharapkan dapat diarahkan untuk mengikuti seluruh proses pembelajaran yang berlangsung menggunakan model pembelajaran kooperatif tipe Think Pair Share (TPS) dengan baik, karena sangat bermanfaat untuk meningkatkan kemampuan siswa dan penerapan model pembelajaran kooperatif tipe 
32 Carolus Ryan Putra Praditya, Kir Haryana

Think Pair Share (TPS) sangat perlu memperhatikan kemampuan penguasaan kelompok supaya situasi belajar tetap kondusif. Hal ini dikarenakan kecenderungan siswa yang akan lebih banyak berbicara dengan siswa lain saat kegiatan berkelompok.

\section{DAFTAR PUSTAKA}

Arikunto, Suharsimi. (2007). Prosedur Penelitian Suatu Pendekatan Praktik. Jakarta: Bumi Aksara.

Hartina. (2008). Pengaruh Model Pembelajaran Kooperatif Tipe Think Pair Share (TPS) terhadap Hasil Belajar Kimia Siswa Kelas XI IPA SMA Negeri 5 Makassar (Studi pada Materi Pokok Laju Reaksi). Skripsi. Jurusan Kimia FMIPA, UNM.

Nurlaila, Fani dan I.G.P Asto Buditjahjanto. (2013). Pengaruh Model Pembelajaran Kooperatif Tipe Think Pair Share Dengan Kecerdasan Logis Matematis Terhadap Hasil Belajar Siswa Di SMK Negeri 3 Surabaya. Surabaya: Jurnal Pendidikan Teknik Elektro. Volume 2 nomor 2 Tahun 2013.

Shoimin, A. (2014). 68 Model pembelajaran inovatif dalam kurikulum 2013. Yogyakarta: ARRUZZ MEDIA.

Surayya, L., I W. Subagia dan I N. Tika. (2014). Pengaruh Model Pembelajaran Think Pair Share Terhadap Hasil Belajar IPA Ditinjau Dari Keterampilan Berpikir Kritis Siswa. Bali: e-Journal Program Pascasarjana Universitas Pendidikan Ganesha Program Studi IPA (Volume 4 Tahun 2014).

Tafakur, T., \& Suyanto, W. (2015). Pengaruh cooperative project-based learning terhadap motivasi dan hasil belajar praktik "perbaikan motor otomotif" di SMKN 1 Seyegan. Jurnal Pendidikan Vokasi, 5(1), 117-131.

Nurtanto, M., \& Sofyan, H. (2015). Implementasi problem-based learning untuk meningkatkan hasil belajar kognitif, psikomotor, dan afektif siswa di SMK. Jurnal Pendidikan Vokasi, 5(3), 352-364. 